\title{
Molecular and cytogenetic assessment of Dipterygium glaucum genotoxicity
}

\author{
NADA H. ALTWATY ${ }^{1}$, OSAMA E. EL-SAYED ${ }^{1,2}$, NARIMAN A.H. ALY ${ }^{1,2}$, \\ MOHAMED N. BAESHEN ${ }^{1}$ and NABIH A. BAESHEN ${ }^{1}$ \\ ${ }^{1}$ Department of Biology, Faculty of Scienc, King Abdulaziz University, P.O. Box 80200, Zip Code 21589, Saudi Arabia \\ ${ }^{2}$ Genetics and Cytology Dept, National Research Centre, El-Buhouth St., \\ Dokki, Postal Code 12311, Zip Code 12622, Cairo, Egypt
}

Manuscript received on March 19, 2015; accepted for publication on June 9, 2015

\begin{abstract}
The aim of the present study is to assess the genotoxicity of Dipterygium glaucum grows widely in Saudi Arabia desert to produce safety herbal products. This work is considered the first and pioneer report so far due to the lack and poor evaluated reports of the plant species for their mutagensity, genotoxicity and cytogenetics effects. Cytogenetic effects of D. glaucum on mitotic in roots of Vicia faba showed reduction in mitotic activity using three extracts; water, ethanol and ethyl acetate. Chromosomal abnormalities were recorded that included stickiness of chromosomes, chromatin bridge, fragments, lagging chromosome and micronuclei. Protein bands and RAPD analyses of $V$. faba treated with three D. glaucum extracts revealed some newly induced proteins and DNA fragments and other disappeared. Chemical constitution of the plant species should be identified with their biological activities against human and animal cells like HeLa cancer cell line. We are recommending using additional genotoxicity tests and other toxicity tests on animal culture with different concentrations and also utilizing several drought and heat tolerant genes of the plant species in gene cloning to develop and improve other economical crop plants instead of using the species as oral herbal remedy
\end{abstract}

Key words: Dipterygium glaucum, three plant extracts, cytogenetic on mitotic roots of Vicia faba, protein and RAPD analyses.

\section{INTRODUCTION}

Saudi Arabia has a hot desert climate and rainfall is scarce in most parts of the country, therefore flora of Saudi Arabia as well as other countries in the peninsula has been neglected for a long time due to its arid climate. Dipterygium glaucum Decne belongs to subclass Dilleniidae order Capparales, family Capparidaceae (Cronquist 1981) is one of

Correspondence to: Nada H. Altwaty

E-mail: naltwaty@yahoo.com such neglected species that is infrequently reported and investigated. Dipterygium glaucum is a perennial shrub which is very common along the Arabian Gulf coast that is often found in a heavily grazed and stunted condition (Moussa et al. 2012). Always growing in the sandy plain habitats and it is one of the sand dunes, forming species that grows in the inland areas far from the red sea coast (AlNafie 2004). D. glaucum suffers from the rarity of water and the very high temperature which affect its phenotypic characters. In spite of that, 
it has multiple medicinal uses by the Bedouins in constructing houses and fences and as fuel source. D. glaucum is a source of volatile alkaloids, flavonoides, cumarins and cyanides in addition to its popular utility as a trachea dilating agency in miss-breathing troubles (Al-Zugut 1989). This species is also used as soil erosion control, shelters against windblown sand, construction material for fences and simple houses, a fuel source.

No reports of genotoxicity, cytogenetic and molecular studies as well as chemical determination and biological activities have been seen for this plant species. According to the World Health Organization, $80 \%$ of the populations in Asian and African countries rely on traditional medicine as their main source of health care. The interest in herbal products worldwide as a re-emerging health aid is fueled by the rising costs of drugs. However, there is limited scientific evidence regarding the safety of the plant sources. The efficacy and safety of herbal products depend on the safety of their sources, and this should be established before these are developed as herbal medicinal products. Although the use of medicinal plants are increasing empirically probably due to the belief that they are harmless simply because they are natural (Atere and Ajao 2009), concern has been raised regarding the toxicity and adverse effects of these remedies (Saad et al. 2006). WHO still directive encourages developing countries to supplement their health program with traditional herbal preparation provided they are proven to be non-toxic (Akintonwa et al. 2009).

The safe use of plants is commonly assumed in traditional medicine. This safety is based on their long usage in the treatment of diseases according to knowledge accumulated over centuries. However, recent scientific data have shown that many plants used as food or in traditional medicine are potentially toxic, mutagenic or carcinogenic (Fennell et al. 2004). In addition, epidemiological data support the idea that tannins, among other vegetal antioxidant agents, have the ability to modulate certain cell signaling pathways and gene expression (Hu and Qin 2006).

Several plants such as Allium cepa, Vicia faba and Zea mays etc. have been used as good bio-indicators of genetic toxicity of environmental pollutants in recent years, and comet assay, micronucleus assay or chromosome aberration assay were used to measure the genotoxic effects (Liu et al. 2005 and Asita and Matebesi 2010).

Advantages of measuring the genotoxicity in plants at DNA level are mainly related to the sensitivity and short response time. PCR-RAPD is extremely efficient for DNA analysis in complex genomes as it is relatively inexpensive and yields information on a large number of loci without having to obtain sequence data for primer design (De Wolf et al. 2004). Furthermore, its use in surveying genomic DNA to detect various types of DNA damage and mutations (e.g., rearrangements, point mutation, small insert or deletions of DNA and ploidy changes) suggested that they may potentially form the basis of novel biomarker assays for the detection of DNA damage and mutations in cells of bacteria, plants and animals (Atienzar et al. 2000). Results that express mutagenic activity suggest that a specific agent is not safe for medicinal use. The positive mutagenicity property may exclude a plant from any further trial of preclinical tests, a crucial step in the development of new agents with clinical relevance (Montanari 2002). The aim of the present study is to assess the genotoxicity of Dipterygium glaucum grow widely in Saudi Arabia desert to produce genetic safety herbal products.

\section{MATERIALS AND METHODS}

\section{PLANT MATERIAL COLLECTION}

Dipterygium glaucum plants were collected in bulk from Jeddah desert (Fig. 1). The bulked plants were washed under running tap water to remove adhering dust. 

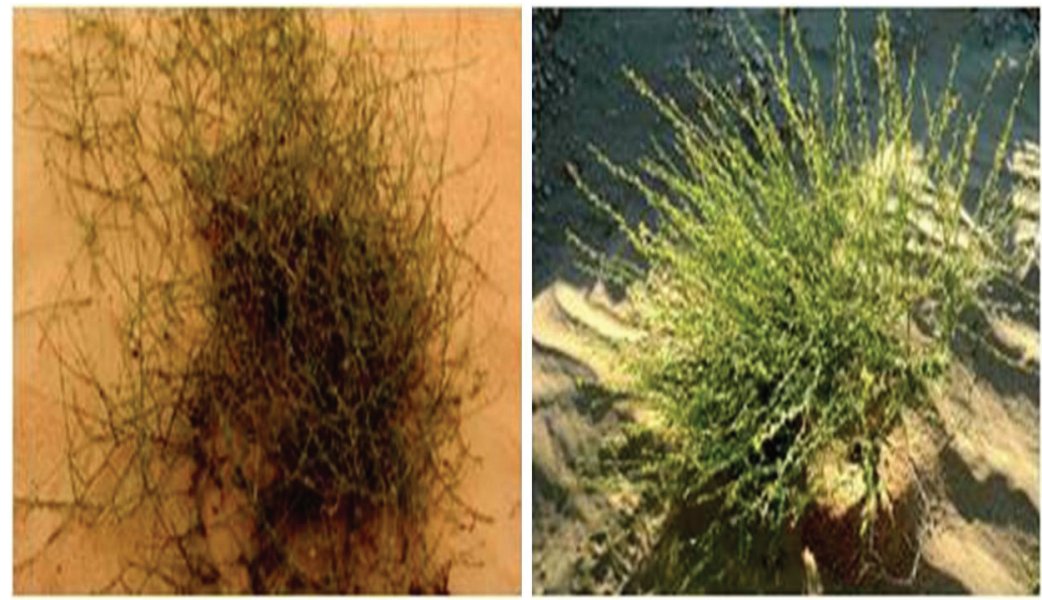

Figure 1 - Dipterygium glaucum plants grown widely in Saudi Arabia desert. (See the colors in the online version).

EXTRACTION AND PREPARATION OF D. glaucum

D. glaucum plants were macerated and were kept in ethanol and ethyl acetate for 7 days at room temperature, while plants were kept in water for the same period in refrigerator to prevent contaminations. The three fractions were filtered through Whatman no. 4 and the obtained filtrates were concentrated separately in a rotary evaporator until dryness. The aqueous water extract was lyophilized using freezedryer. Each of the dryness extract was dissolved in $3 \mathrm{ml}$ of $70 \%$ ethanol and was kept in the refrigerator for molecular evaluation in $V$. faba leaves and $S$. cerevisiae strains. Aqueous extracts were tested because decoctions of these plants with water only are used in traditional medicine (Sinha 1996) and the primary aim of this study was to determine whether the chemicals present in the preparations of these plants used in traditional medicine interact with genetic material.

EVALUATION OF GENOTOXICITY OF D. glaucum EXTRACTS WITH $V$. faba ASSAY

Vicia faba root tip test was conducted according to Yi and Si (2007). Dry seeds of $V$. faba (Giza 3) stored at $4^{\circ} \mathrm{C}$ and were soaked in water for $24 \mathrm{~h}$. Then the seeds were allowed to germinate between two layers of moist cotton at $23^{\circ} \mathrm{C}$ in the dark for 3 days. Seedlings of $V$. faba with roots about $4 \mathrm{~cm}$ in length were treated with three Dipterygium glaucum extracts (water, ethyl acetate and ethanol) for 6, 12 and $24 \mathrm{~h}$ under constant aeration. For each treatment ten seedlings were used in three replications. The treatments were terminated by giving quick wash to the seedlings in running tap water, following which they were kept for $45 \mathrm{~h}$ in well aerated tap water according to Kihlman (1971).

FIXATION AND STAINING OF ROOT TIPS

For preparation of metaphase chromosomes, root tips were cut and fixed overnight in Carnoy's fixative that contains three parts methanol and one part glacial acetic acid and were kept at $4^{\circ} \mathrm{C}$ until later use. For preparing the root tips smears, they were transferred to room temperature in distilled water for $5 \mathrm{~min}$. The root tips were then hydrolyzed in $1 \mathrm{~N} \mathrm{HCl}$ at $60^{\circ} \mathrm{C}$ for $7 \mathrm{~min}$. Preparation of slides from the fixed root tips was done following acetocarmine squash technique (1\% solution of carmine in $45 \%$ acetic acid). Freshly fixed materials were transferred into $1 \%$ acetocarmine for at least 30 min and then were analyzed by the squash method. The slides were observed under $400 \times$ magnification optical light microscopes ECLIPSE (Nikon Instruments, Japan). The frequency and types of traditional chromosome aberration were determined by examining about 1000 metaphases 
from 10 root tips per treatment, and those of abnormal chromosome behavior were determined by examining 1000 metaphase and anaphase cells. Mitotic index and micronucleus frequency were determined from 10 root tips by examining 1000 cells per root tip. The mitotic index (MI) will be calculated as the number of dividing cells per 1000 observed cells (Fiskesjo 1997). The frequency of aberrant cells (CA\%) was calculated according to Bakare et al. (2000). MI = Number of dividing cells/Total number of cells counted X 100 .

Frequency of CA $(\%)=$ Number of aberrant cells/ Total number of cells counted X 100

\section{SDS-PAGE PROTEIN ANALYSIS}

Sodium dodecyl sulfate polyacrylamide gel electrophoresis (SDS-PAGE) was used according the method of Laemmli (1970) in order to detect the genetic variations in protein profiles due to Dipterygium glaucum three extract treatments. Leaves of $V$. faba seedling stage treated with the three D. glaucum extracts (water, ethyl acetate and ethanol) for $24 \mathrm{~h}$ were extracted with total protein buffer. Leaves were ground with liquid nitrogen (LN) and powders were transferred to eppendorf tubes with $1 \mathrm{ml}$ of extraction buffer and left in refrigerator overnight. They were centrifuged for $10 \mathrm{~min}$ at $12,000 \mathrm{rpm}$ under $4^{\circ} \mathrm{C}$. The supernatants containing protein fraction were transferred to new tubes and were stored at $-20^{\circ} \mathrm{C}$ until use for electrophoretic analysis. Electrophoresis was carried out at $4^{\circ} \mathrm{C}$ until the bromophenol blue front passed completely through the gel. The gel was stained with Commassie brilliant blue - R250 staining methods. Protein gels were scanned using Gel Doc 2000 system and were analyzed with software supplied by the manufacturer.

DNA EXTRACTION AND RAPD ANALYSIS IN Vicia faba TREATED WITH D. glaucum

Random amplified polymorphic DNA (RAPD) was used for detection the genotoxicity and/or DNA damage caused by $D$. glaucum that extracted with three treatments. DNA extraction using CTAB method (Doyle and Doyle 1987) was performed from leaves of $V$. faba seedlings treated with the three D. glaucum extracts (water, ethyl acetate and ethanol) for $24 \mathrm{~h}$. Leaf tissue was powered in liquid nitrogen and added in $12 \mathrm{ml}$ of pre-warmed $65^{\circ} \mathrm{C}$ CTAB buffer $(2 \% \mathrm{w} / \mathrm{v}$ CTAB, $0.1 \mathrm{M}$ Tris ( $\mathrm{HCl}, \mathrm{pH}$ 8.0, $20 \mathrm{mM}$ EDTA, $1.4 \mathrm{M} \mathrm{NaCl}$ 1\% w/v PVP), containing $120 \mu 1$ beta mercaptoethanol, till a thick paste was obtained. The mixture was incubated at $65^{\circ} \mathrm{C}$ for $1 \mathrm{~h}$. The slurry was cooled to room temperature and $10 \mathrm{ml}$ chloroform: isoamyl alcohol $(24: 1 \mathrm{v} / \mathrm{v})$ was added and was stirred gently several times to mix the two phases. The mixture was centrifuged at $12000 \mathrm{rpm}$ for 15 min at room temperature. The aqueous phase was recovered into a fresh sterile tube and the previous step was repeated. The aqueous phase was once again recovered into a fresh sterile tube. To it equal volume of isopropanol and $1 \mathrm{ml}$ of $5 \mathrm{M} \mathrm{NaCl}$ was added and was mixed gently by repeated and left at $\left(20^{\circ} \mathrm{C}\right.$ overnight. The mixture was centrifuged at $8000 \mathrm{rpm}$ for $10 \mathrm{~min}$ at $4^{\circ} \mathrm{C}$ and the pellet was washed twice with $70 \%$ alcohol. The pellet was air dried briefly and was rehydrated in $100 \mu 1$ of TE (10 mM Tris-HCl, pH 8.0, 1 mM EDTA). RAPD analysis was performed using three 10-mer random primers (Metabion, Martinsried, Germany) as shown in Table I.

TABLE I

The random primer names and sequences used for RAPD analysis.

\begin{tabular}{ll}
\hline Primer name & Sequence $\left(\mathbf{5}^{\prime}\right.$ ' 3$)$ \\
\hline B-14 & 5' GTT TCG CTC C '3 \\
C-15 & 5' TTT GGG GGG A '3 \\
B-08 & 5' GGG TAA CGC C '3 \\
\hline
\end{tabular}

RAPD amplification reaction was used in a final volume of $25 \mu \mathrm{l}$ containing 10X PCR buffer (50 mM KCl, $10 \mathrm{mM}$ Tris- $\mathrm{HCl}, 1.5 \mathrm{mM} \mathrm{MgCl}_{2}$, $\mathrm{pH}$ 9.0), $2 \mathrm{mM}$ dNTPs, $10 \mathrm{mM}$ primer, $50 \mathrm{ng}$ 
of template DNA and $0.5 \mathrm{U}$ of Taq polymerase (Promega, USA). Reactions were performed in a thermocycler (Biometra, GmbH). RAPD-PCR was performed according to Williams et al. (1990) as one cycle of $94^{\circ} \mathrm{C}$ for $2.5 \mathrm{~min}$ (denaturation), 30 cycles of $\left\{94^{\circ} \mathrm{C}\right.$ for $1 \mathrm{~min}, 37^{\circ} \mathrm{C}$ for $1 \mathrm{~min}$ and $72^{\circ} \mathrm{C}$ for $1 \mathrm{~min}$ (annealing) $\}$ and a final extension of 10 min at $72^{\circ} \mathrm{C}$. PCR products were analyzed using $1.2 \%$ agarose gel electrophoresis and visualized with $10 \mu \mathrm{g} / \mu 1$ ethidium bromide staining. The sizes of the fragments were estimated based on a DNA ladder of 100 to $2000 \mathrm{bp}$ (MBI, Fermentas).

\section{RESULTS AND DISCUSSION}

CYTOGENETIC EFFECTS OF D. glaucum ON RoOT MERISTEM OF $V$. faba

Extensive literature survey has not shown any reports of cytogenetic effects of D. glaucum. Therefore the present work is considered the first and pioneer report so far that describes the cytogenetic effects of three extracts of D. glaucum Decne on root meristem of Vicia faba. The cytogenetic effect of D. glaucum on mitotic in roots of $V$. faba was evaluated. Reduction in mitotic activity was induced using three different extracts of $D$. glaucum. A considerable frequency of chromosomal abnormalities was also recorded. The cytological observation revealed that $D$. glaucum has a strong mitostatic effect on $V$. faba root as evident by the mitotic index which decreases with the increases in duration from 4 to $12 \mathrm{~h}$ (Table II).

The stickiness of chromosomes (Fig. 2) was the most prominent aberration induced by the extracts. The stickiness of chromosomes might have resulted due to loosening of nucleic acid from the protein architecture of the chromosomes or due to depolymerization of DNA (Ma et al. 2012) and partial dissolution of nucleoprotein. At higher concentration the stickiness of cells was very common. The chromatin bridge (Fig. 2) was observed due to the sticky nature of chromosomes, inversions and high frequency. This effect was previously recorded by Haroun and Shehri (2001). The fragments (Fig. 2) were noticed either due to terminal breaks in the chromosome or failure of chromosome thread to rejoin (Sousa et al. 2009). The lagging chromosome (Fig. 2) was possibly formed due to the inhibition of centromeric and spindle activity which inhibits chromosome movement and due to presence of acentric fragments or to the interaction of drug with protein of the spindle apparatus. Lagging chromosomes were resulted

TABLE II

Abnormal mitosis and types of mitotic abnormalities in Vicia faba (Giza 3) after root treatments f with different extracts of Dipterygium glaucum.

\begin{tabular}{|c|c|c|c|c|c|c|c|c|c|c|c|}
\hline \multirow{2}{*}{ Extracts } & \multirow{2}{*}{$\begin{array}{c}\text { Treatment } \\
\text { duration (h) }\end{array}$} & \multirow{2}{*}{$\mathbf{T M}$} & \multirow{2}{*}{ TA } & \multirow{2}{*}{ TA \% } & \multicolumn{7}{|c|}{ Types of abnormal mitosis } \\
\hline & & & & & $\mathbf{F}$ & $\mathbf{L}$ & D & $\mathbf{S}$ & $\mathbf{M}$ & B & $\mathbf{U}$ \\
\hline Control & & 190 & 3 & 1.36 & 0 & 0 & 0 & 0 & 0 & 0 & 0 \\
\hline \multirow{3}{*}{ Water } & 6 & 163 & 16 & 11.26 & 1 & 2 & 4 & 6 & 2 & 2 & 1 \\
\hline & 12 & 150 & 13 & 8.39 & 1 & 1 & 2 & 5 & 0 & 3 & 1 \\
\hline & 24 & 138 & 19 & 15.57 & 2 & 1 & 2 & 5 & 2 & 3 & 2 \\
\hline \multirow{3}{*}{ Ethanol } & 6 & 132 & 15 & 10.64 & 2 & 2 & 3 & 8 & 1 & 4 & 2 \\
\hline & 12 & 111 & 21 & 16.67 & 3 & 2 & 3 & 6 & 2 & 3 & 2 \\
\hline & 24 & 141 & 22 & 18.92 & 2 & 1 & 2 & 4 & 2 & 3 & 1 \\
\hline \multirow{3}{*}{ Ethyl acetate } & 6 & 129 & 18 & 13.95 & 2 & 2 & 2 & 6 & 2 & 3 & 1 \\
\hline & 12 & 107 & 23 & 21.50 & 2 & 2 & 3 & 8 & 2 & 4 & 2 \\
\hline & 24 & 96 & 23 & 23.96 & 4 & 1 & 2 & 9 & 1 & 3 & 3 \\
\hline
\end{tabular}

$\mathbf{T M}=$ Total cells in mitosis; $\mathbf{T A}=$ Total abnormal cells, $\mathbf{T A} \%=$ percentage of total abnormalities; $\mathbf{F}=$ Fragment, $\mathbf{L}=\mathrm{Lagging}$, $\mathbf{D}=$ Disturbance, $\mathbf{S}=$ Sticky, $\mathbf{M}=$ Micronuclei, $\mathbf{B}=$ Bridge $\mathbf{U}=$ Unseparated, Total no. of examined cells (1000 cells). 
due to the failure of the chromosomes to move to either of the poles. The percentage of laggards, fragments and bridges indicated the clastogenic effects of Dipterygium glaucum on Vicia faba cells. Dipterygium glaucum extracts behaved as stathmokinetic agent Lubini et al. (2008) since its effects was on the spindle as evident by less number of abnormalities was found in prophase. Thus the present study suggested that injudicious use of D. glaucum lead to several genetic deformities in bioorganisms and specific dose and duration of therapy would be useful in controlling diseases

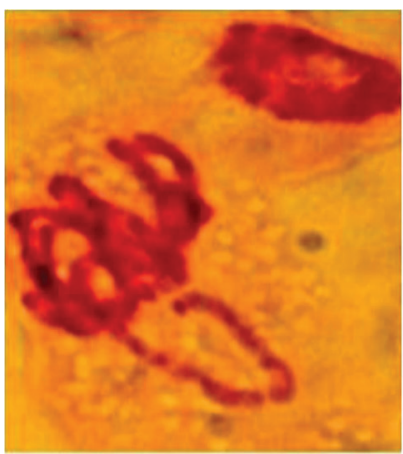

1

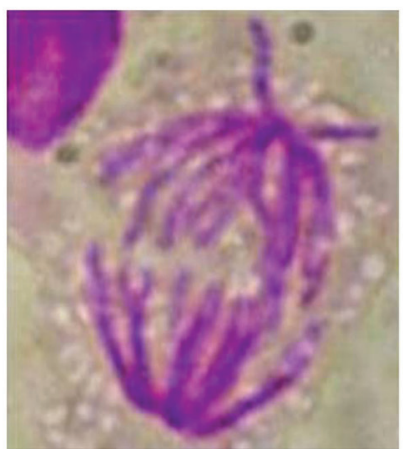

5

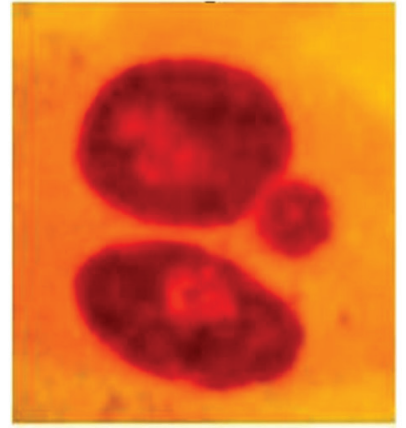

9

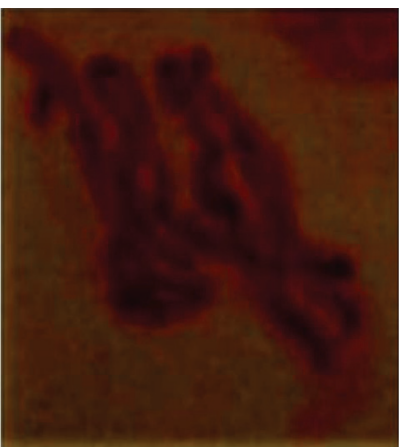

2

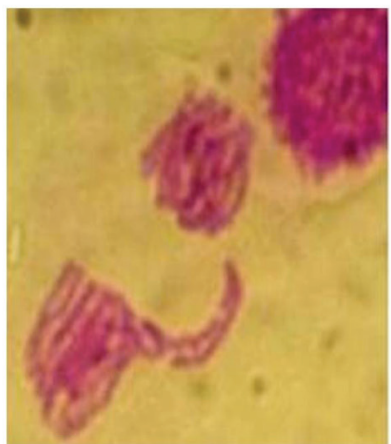

6

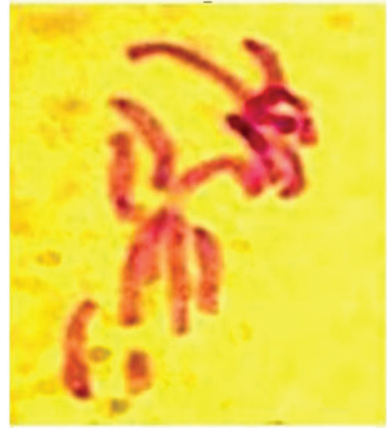

10

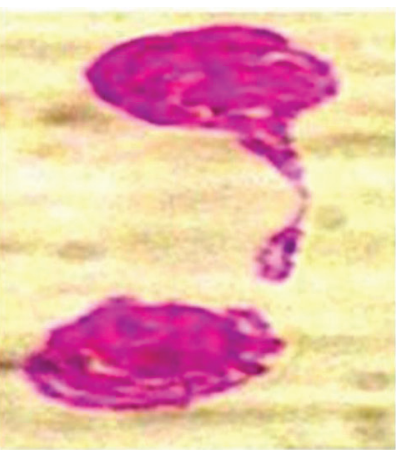

3

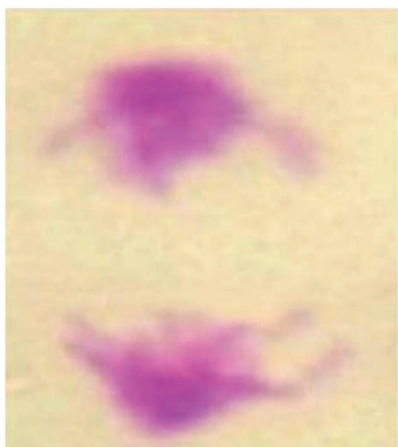

7

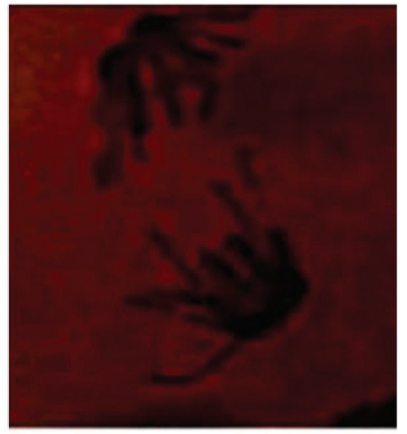

11

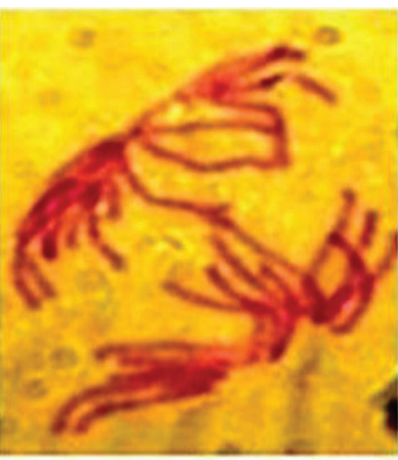

4

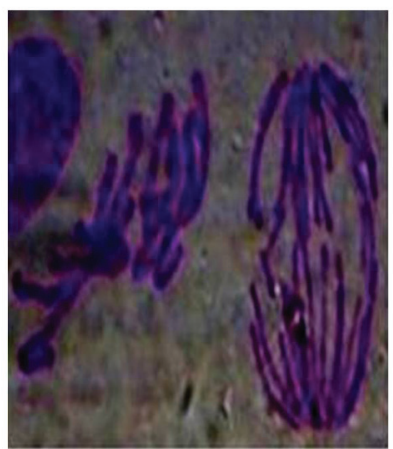

8

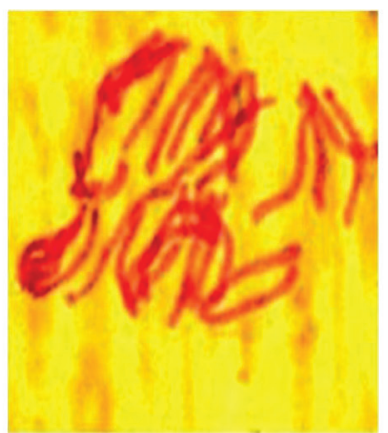

12

Figure 2 - Types of abnormalities in $V . f a b a$ (Giza 3) root-tip meristems after root treatment for 6, 12 and 24 h with three extracts of D. glaucum Decne. 1. Sticky prophase with lagging chromosome, 2. Sticky metaphase, 3. Sticky telophase with broken bridge, 4. Sticky anaphase with broken bridge, 5. Anaphase with bridge and forward chromosome, 6. Sticky anaphase, 7. Anaphase with bridge, 8. Unseparated anaphase, 9. Micronuclei, 10. Disturbed anaphase with fragment and laggard chromosome, 11. Anaphase with broken bridge and fragment, 12. Disturbed anaphase with lagging chromosome. (See the colors in the online version). 
Number of factors can be contributing to the increased chromosomal aberrations. The most important one is due to the interference of $D$. glaucum constitutions during DNA repair. Different types of chromosomal aberrations by the secondary metabolites existing in D. glaucum represent their clastogenicity. The chromosome gaps which involve only the loss of chromatin may be due to the loss of protein part of the chromosome. The chromatid breaks, which represent the DNA double strand breaks that may not have undergone the $\mathrm{G} 2$ repair. Any such irreversible DNA damages will lead to the chromosomal aberrations. Irreversible DNA damage would be produced whenever the trapped cleavable complex collides with a replication fork, independently of whether it is euchromatic or heterochromatic regions of the chromosomes that are being replicate. Root tips frequently used for cytogenetic studies in the past five decades were from $V$. faba (Sobita and Bhagirath 2005) which are excellent materials for clastogenicity studies of physical and chemical agents. Thus, our results suggest caution in the use of D. glaucum in folk medicine. Finally, serious problems and damages on cells by incorrectly usage can be observed. In order to obtain more information and precise conclusions about $D$. glaucum, further researches should be performed with different models and systems.

THE EFFECTS OF D. glaucum EXTRACTS ON $V$. faba PROTEIN PROFILE BANDS

A total of 31 protein bands ranged from 238 to $10 \mathrm{kD}$ were detected using SDS-PAGE of $V$. faba bean treated with $D$. glaucum extracts as shown in Fig. (3) and Table III. The effects of the three $D$. glaucum extracts were clearly observed among the detected protein bands in $V$. faba leaves. Whereas seven bands with 109, 68, 58, 31, 26, 14 and 11 $\mathrm{kD}$ were observed in control, which did not exist in the water extract. Moreover eight newly introduced bands were detected in the $V$. faba treated with $D$. glaucum ethyl acetate extract which did not exist in the controls. Such newly protein bands were introduced due to the D. glaucum ethyl acetate extract treatment.

On the other hand, some distinctive protein bands were characterized the $V$. faba treated with D. glaucum ethanol extract. For instance, two bands with 238 and $59 \mathrm{kD}$ disappeared in faba bean treated with $D$. glaucum ethyl acetate extract while appeared in $V$. faba treated with D. glaucum ethanol extract. The total number of protein band clearly increased in D. glaucum ethanol and ethyl acetate extracts with 30 and 29, respectively. While, V.faba treated with $D$. glaucum aqueous extract showed 26 versus 24 in the control (untreated V. faba plants).

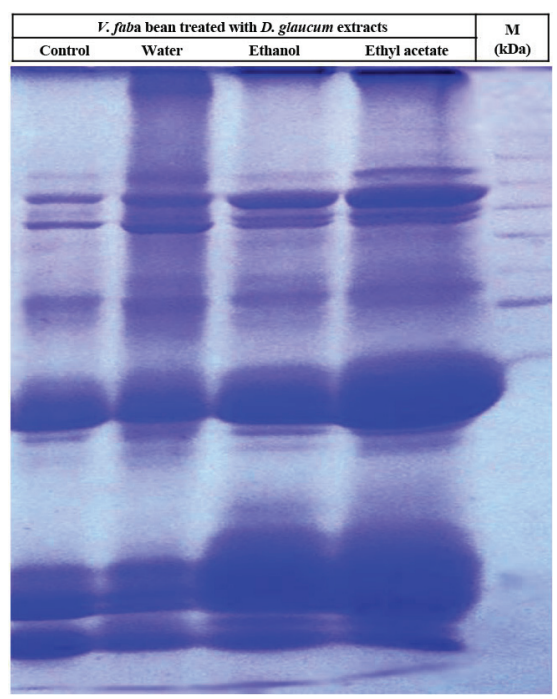

Figure 3 - SDS-PAGE protein patterns of $V$. faba leaves treated with different $D$. glaucum extracts. (See the colors in the online version).

TABLE III

SDS-PAGE analysis of $V \cdot f a b a$ protein bands extracted from the leaf and treated with different $D$. glaucum extracts.

\begin{tabular}{cccccc}
\hline Band & MW & \multicolumn{5}{c}{ Vicia faba treated with D. glaucum extracts } \\
\cline { 3 - 6 } No. & (kD) & Control & Water & Ethanol & Ethyl acetate \\
\hline 1 & $\mathbf{2 3 8}$ & + & & + & \\
2 & $\mathbf{1 6 1}$ & + & & + & + \\
3 & $\mathbf{1 0 9}$ & & + & + & + \\
4 & $\mathbf{9 2}$ & + & + & + & + \\
5 & $\mathbf{8 5}$ & + & + & + & + \\
\hline
\end{tabular}


TABLE III (continuation)

\begin{tabular}{|c|c|c|c|c|c|}
\hline \multirow{2}{*}{$\begin{array}{l}\text { Band } \\
\text { No. }\end{array}$} & \multirow{2}{*}{$\begin{array}{l}\text { MW } \\
\text { (kD) }\end{array}$} & \multicolumn{4}{|c|}{ Vicia faba treated with $D$. glaucum extracts } \\
\hline & & Control & Water & Ethanol & Ethyl acetate \\
\hline 6 & 74 & + & + & + & + \\
\hline 7 & 68 & & + & + & + \\
\hline 8 & 63 & + & + & + & + \\
\hline 9 & 59 & + & & + & \\
\hline 10 & 58 & & + & + & + \\
\hline 11 & 55 & + & + & + & + \\
\hline 12 & 52 & + & + & + & + \\
\hline 13 & 50 & + & + & + & + \\
\hline 14 & 46 & + & & & + \\
\hline 15 & 40 & + & + & + & + \\
\hline 16 & 38 & + & + & + & + \\
\hline 17 & 36 & + & + & + & + \\
\hline 18 & 34 & + & + & + & + \\
\hline 19 & 33 & + & + & + & + \\
\hline 20 & 31 & & + & + & + \\
\hline 21 & 28 & + & + & + & + \\
\hline 22 & 26 & & + & + & + \\
\hline 23 & 24 & + & + & + & + \\
\hline 24 & 22 & + & + & + & + \\
\hline 25 & 20 & + & + & + & + \\
\hline 26 & 19 & + & + & + & + \\
\hline 27 & 18 & + & + & + & + \\
\hline 28 & 17 & + & + & + & + \\
\hline 29 & 14 & & + & + & + \\
\hline 30 & 11 & & & + & + \\
\hline 31 & 10 & + & + & + & + \\
\hline Total b & $\mathrm{nds}=31$ & 24 & 26 & 30 & 29 \\
\hline Induce & bands & -- & -- & 7 & 2 \\
\hline
\end{tabular}

RAPD-PCR ANALYSIS OF $V$. faba TREATED WITH $D$. glaucum EXTRACTS

Three arbitrary random amplified polymorphic DNA (RAPD) primers; B-14, C-15 and B-08 were used to amplify DNA extracted from $V$. faba treated with three different $D$. glaucum extracts. A total of 42 amplified DNA fragments ranging in size from 1986 to $121 \mathrm{bp}$ were observed using the three primers, whereas 19 fragments were polymorphic and the other amplified fragments were commonly detected under D. glaucum extracts. (Table IV) The three primers; B-14, C-15 and B-08 showed mean polymorphic percentage $49 \%$, whereas the polymorphic percentage of primers $\mathrm{B} 0-14$ and C-15 were higher than primer B-08 (55 and 53\% vs. $31 \%$, respectively). RAPD analysis of primer B-14 showed 6 polymorphic fragments of a total of 11 with sizes ranged from 1721 to $172 \mathrm{bp}$, while primer C-15 displayed 8 polymorphic of a total of 15 with sizes from 1244 to $121 \mathrm{bp}$ and primer B-08 showed 5 polymorphic from 16 fragments with sizes from 1986 to $113 \mathrm{bp}$. However, the other fragments among the three primers were commonly detected under the three D. glaucum extracts (Fig. 4 and Table IV). RAPD-PCR analysis of $V$. faba treated with three D. glaucum extracts using three random primers; B-14, C-15, and B-08 revealed some distinctive bands that were existing in the control and disappeared in treated $V$. faba with three extracts. For instant, a fragment with 546 bp appeared only in the control in primer B-14 and a fragment 1986 bp with primer B-08. Some other fragments were induced in the treated $V$. faba, which did not exist in the control. For example a fragment $648 \mathrm{bp}$ with primer B-14 and 152 bp with primer $\mathrm{C}-15$ were induced under the three extracts. A fragments 1721 bp with primer B-14 induced under water extract only and another fragment 1462 with B-08 induced under water and chloroform extracts.

$V$. faba leaves were soundly affected by $D$. glaucum ethyl acetate extract comparing with the other two extracts, whereas four fragments disappeared and appeared in the control and other extracts. For examples, two fragments 220 and 121 bp with primer C-15 and two others fragments 1328 and $879 \mathrm{bp}$ with primer B-08. $V$. faba treated with D. glaucum water extract showed similar amplified fragments with the control in two primers, two fragments 1254 and 1077 bp with primer B-14 and two other fragments 1244 and 290 bp with primer $\mathrm{C}-15$. Moreover, water extract revealed a unique fragment 1721 bp with primer B-14 that disappeared in the other two extracts as well as in the control. However, two fragments 894 and 196 bp with C-15 
and 315 bp with B-14 disappeared in bean treated with $D$. glaucum aqueous extract and existed in the control and other extracts. $V$. faba leaves affected by $D$. glaucum ethanol extract in one fragment 378 bp with primer B-08 that disappeared while existed in the other extracts and in the control.

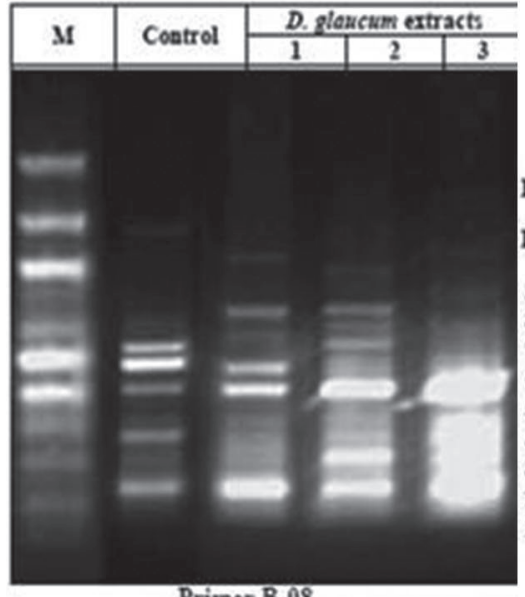

Primer B-08

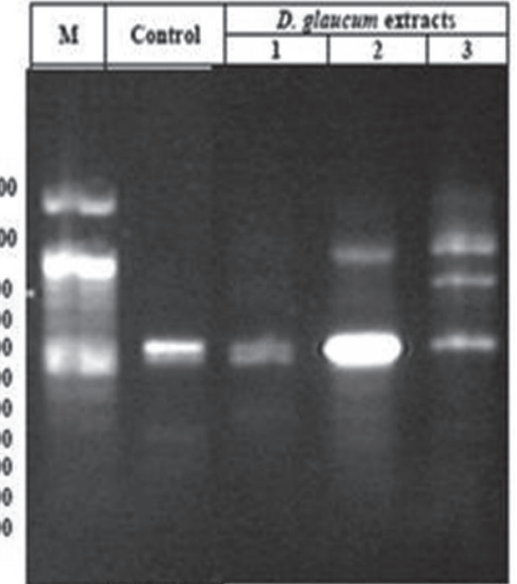

Primer B-14

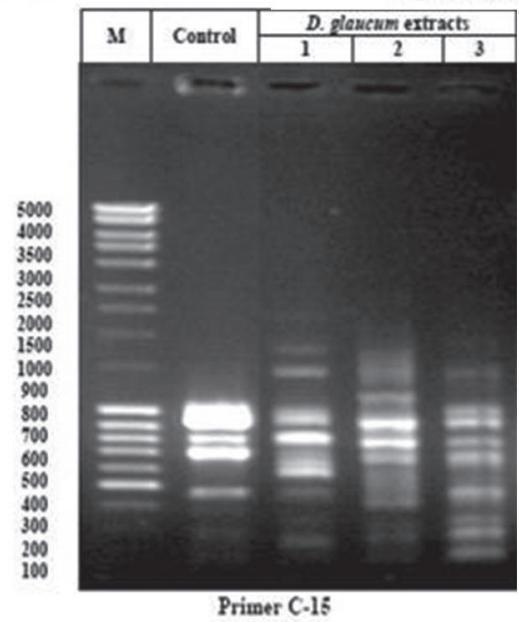

Figure 4 - RAPD amplified products of Vicia faba treated with three D. glaucum extracts using three random primers. 1. Water extract, 2. Ethanol extract, 3. Ethyl acetate extract.

TABLE IV

RAPD analysis of Vicia faba treated with three D. glaucum extracts using three random primers.

\begin{tabular}{|c|c|c|c|c|c|c|c|}
\hline \multirow{2}{*}{$\begin{array}{c}\text { Primer } \\
\text { name }\end{array}$} & \multirow{2}{*}{$\mathrm{P} \%$} & \multirow{2}{*}{ Fragment no } & \multirow{2}{*}{$\begin{array}{l}\text { Fragment size } \\
\text { (bp) }\end{array}$} & \multicolumn{4}{|c|}{ D. glaucum extracts } \\
\hline & & & & Control & Water & Ethanol & Ethyl acetate \\
\hline \multirow{8}{*}{ B-14 } & \multirow{8}{*}{55} & 1 & 1721 & & + & & \\
\hline & & 2 & 1254 & + & + & & \\
\hline & & 3 & 1077 & + & + & & \\
\hline & & 6 & 648 & & + & + & + \\
\hline & & 7 & 546 & + & & & \\
\hline & & 9 & 315 & + & & + & + \\
\hline & & Total $=11$ & & 4 & 4 & 0 & ? \\
\hline & & Variable fragm & $\mathrm{nts}=6$ & 4 & 4 & 2 & 2 \\
\hline
\end{tabular}


TABLE IV (continuation)

\begin{tabular}{|c|c|c|c|c|c|c|c|}
\hline \multirow{2}{*}{$\begin{array}{l}\text { Primer } \\
\text { name }\end{array}$} & \multirow{2}{*}{$\mathrm{P} \%$} & \multirow{2}{*}{ Fragment no } & \multirow{2}{*}{$\begin{array}{l}\text { Fragment size } \\
\text { (bp) }\end{array}$} & \multicolumn{4}{|c|}{ D. glaucum extracts } \\
\hline & & & & Control & Water & Ethanol & Ethyl acetate \\
\hline \multirow{8}{*}{$\mathrm{C}-15$} & \multirow{8}{*}{53} & 1 & 1244 & + & + & \multirow{3}{*}{+} & \multirow{3}{*}{+} \\
\hline & & 3 & 894 & + & & & \\
\hline & & 9 & 290 & + & + & & \\
\hline & & 11 & 220 & + & + & + & \\
\hline & & 12 & 196 & + & & + & + \\
\hline & & 14 & 152 & & + & + & + \\
\hline & & 15 & 121 & + & + & + & \\
\hline & & \multicolumn{2}{|c|}{ Total $=15$} & 6 & 5 & 5 & 3 \\
\hline \multirow{7}{*}{ B-08 } & \multirow{6}{*}{31} & 1 & 1986 & \multirow[t]{2}{*}{+} & + & & \multirow[b]{5}{*}{+} \\
\hline & & 3 & 1462 & & + & + & \\
\hline & & 4 & 1328 & + & + & + & \\
\hline & & 6 & 879 & + & + & + & \\
\hline & & 11 & 378 & + & + & & \\
\hline & & $\begin{array}{l}\text { Total }=16 \\
\text { Variable fragm }\end{array}$ & $n t s=5$ & 4 & 4 & 3 & 1 \\
\hline & $49 \%$ & \multicolumn{2}{|c|}{$\begin{array}{l}\text { Overall total fragments }=42 \\
\text { Total variable fragments }=19\end{array}$} & 14 & 13 & 10 & 6 \\
\hline
\end{tabular}

$\mathrm{P} \%=$ polymorphic percentage.

The cytogenetic effect of Dipterygium glaucum Decne on mitotic in roots of Vicia faba showed stickiness of chromosomes (Fig. 2) that was the most prominent aberration induced by the extracts. The stickiness of chromosomes might have resulted due to loosening of nucleic acid from the protein architecture of the chromosomes or due to depolymerization of DNA (Ma et al. 2012) and partial dissolution of nucleoprotein. At higher concentration the stickiness of cells was very common. The chromatin bridge (Fig. 2) was observed due to the sticky nature of chromosomes, inversions and high frequency. This effect was previously recorded by Haroun and Shehri (2001). The fragments were noticed either due to terminal breaks in the chromosome or failure of chromosome thread to rejoin (Sousa et al. 2009). The lagging chromosome was possibly formed due to the inhibition of centromeric and spindle activity which inhibits chromosome movement and due to presence of acentric frag- ments or to the interaction of drug with protein of the spindle apparatus. Lagging chromosomes were resulted due to the failure of the chromosomes to move to either of the poles. The percentage of laggards, fragments and bridges indicated the clastogenic effects of $D$. glaucum on $V$. faba cells. $D$. glaucum extracts behaved as stathmokinetic agent Lubini et al. (2008) since its effects was on the spindle as evident by less number of abnormalities was found in prophase. Thus the present study suggested that injudicious use of D. glaucum lead to several genetic deformities in bioorganisms and specific dose and duration of therapy would be useful in controlling diseases

Number of factors can be contributing to the increased chromosomal aberrations. The most important one is due to the interference of $D$. glaucum constitutions during DNA repair. Different types of chromosomal aberrations by the secondary metabolites existing in D. glaucum represent their 
clastogenicity. The chromosome gaps which involve only the loss of chromatin may be due to the loss of protein part of the chromosome. The chromatid breaks, which represent the DNA double strand breaks that may not have undergone the G2 repair. Any such irreversible DNA damages will lead to the chromosomal aberrations. Irreversible DNA damage would be produced whenever the trapped cleavable complex collides with a replication fork, independently of whether it is euchromatic or heterochromatic regions of the chromosomes that are being replicate. Root tips frequently used for cytogenetic studies in the past five decades were from $V$. faba (Sobita and Bhagirath 2005) which are excellent materials for clastogenicity studies of physical and chemical agents. The changes in the protein band patterns between the control and the $V$. faba treated with three D. glaucum extracts (Fig. 3 and Table III) are an indication that the mechanism of action of the extract may be due to interaction with the nuclear materials (Oladunmoye et al. 2007). The variation in the DNA profiles of the control without extracts and three D. glaucum extracts (Fig. 4 and Table IV) suggest that the extract is mutagenic. This is in agreement with the work of Lei et al. (2006) while analyzing Y-type gene specific markers reported that interaction of chemical mutagens brings about variation in the DNA profile of hexaploid wheat.

Organisms when continuously exposed to environmental stress may result in DNA damage. The explorations of RAPD as genetic markers have improved the detection of DNA alterations after the influence of many genotoxins. RAPD-PCR is one of the most reliably used techniques for detecting DNA damage as the amplification stops at the site of the damage. The changes occurring in RAPD profiles following genotoxic treatments include variation in band intensity as well as gain or loss of bands. This has been done through the analysis of band intensities and/or band gain/loss variation between exposed and nonexposed individuals.
Indeed, the gain/loss or intensity differences of RAPD bands may be related to DNA damage, mutations or structural rearrangements induced by genotoxins, affecting the primer sites and/or interpreting distances (Lalrotluanga et al. 2011).

\section{ACKNOWLEDGMENTS}

This project was funded by the Deanship of Scientific Research (DSR), King Abdulaziz University, Jeddah, under grant no. (200/247/ 1433). The authors, therefore, acknowledge with thanks DSR technical and financial support.

\section{RESUMO}

O objetivo do presente estudo foi avaliar a genotoxicidade do Dipterygium glaucum que se desenvolve amplamente no deserto da Arábia Saudita produzindo produtos de ação protetora à base de plantas. Este trabalho é uma pesquisa pioneira no assunto devido à falta de pesquisas sobre espécies de plantas e à sua mutagenicidade, genotoxicidade e efeitos citogenética. Efeitos citogenéticos de D. glaucum sobre estudos mitóticos em raízes de Vicia faba mostrou redução na atividade mitótica usando três extratos; água, etanol e acetato de etila. Anormalidades em cromossomos foram evidenciadas, as quais incluem a aderência de cromossomos, ponte cromatinicas, fragmentos de cromossomos e micronúcleos. Bandas de proteínas e análises de RAPD em $V$. faba tratadas com três extratos de D. glaucum revelaram algumas proteínas induzidas, fragmentos de DNA e outros não identificados. A composição e avaliação química de determinadas espécies de plantas devem ser identificadas visualizando as suas atividades biológicas contra células de câncer humanas e animais, e linhagem celular de células HeLa. Assim, estamos desenvolvendo o uso de testes de genotoxicidade adicionais e outros testes de toxicidade sobre a cultura animal com diferentes concentrações e também utilizando vários genes de plantas resistentes ao calor para desenvolver e melhorar outras plantas cultivadas em vez de usar espécies como fármacos via oral.

Palavras-chave: Dipterygium glaucum, três extratos de plantas, citogenética mitótica em raízes de Vicia faba, analise de proteína e análise de RAPD. 


\section{REFERENCES}

Akintonwa A, Awodele O, Afolayan G And CoKer HA. 2009. Mutagenic screening of some commonly used medicinal plants in Nigeria. J Ethnopharmacol 125: 461470.

AL-NAFIE AH. 2004. Plant Geography of Saudi Arabia. National King Fahd Library, Riyad, KSA.

AL-ZUGUT MF. 1989. Wild plants of Al-Jubail and Yanbou. Aspects and Uses. Royal Inst. of Al-Jubail and Yanbou, Riyad, K.S.A.

ASITA AO AND MATEBESI LP. 2010. Genotoxicity of hormoban and seven other pesticides to onion root tip meristematic cells. Afric J Biotech 9: 4225-4232.

ATERE TG AND AJAO AT. 2009. Toxicological implications of crude alkaloidal fraction from Cnestis ferruginea D.C. root on liver function indices of male Wistar rats. IJBHS 5: 145-155.

ATIENZAR FA, CORDI B, DONKIN MB, EVENDEN AJ, JHA AN AND DEPLEDGE MH. 2000. Comparison of ultravioletinduced genotoxicity detected by random amplified polymorphic DNA with chlorophyll fluorescence and growth in a marine macroalgae, Palmaria palmate. Aquat Toxicol 50: 1-12.

BAKARE AA, MOSURO AA AND OSIBANJO O. 2000. Effect of simulated leachate on chromosomes and mitosis in roots of Allium cepa L. J Environ Biol 21: 263-271.

CRONQUIST AJ. 1981. An Integrated System of Classification of Flowering Plants. Integr Syst Class Columbia University Press, New York, p. 1-1262.

DE Wolf H, BLust R And Backeljiau T. 2004. The use of RAPD in ecotoxicology: A review. Mutat Res 566: 249262.

DOYLE JJ AND DOYLE JL. 1987. A rapid DNA isolation procedure for small quantities of fresh leaf tissue. Phytochem B 19: 11-15.

FENNELL CW, LINDSEY KL, MCGAW LJ, SPARG SG, STAFFORD GI AND ElgORASHI EE. 2004. Assessing African medicinal plants for efficacy and safety: pharmacological screening and toxicology. J Ethnopharmacol 94: 205-217.

FISKESJO G. 1997. Allium test for screening chemicals; evaluation of cytologic parameters. Wang W, Gorsuch JW and Hughes JS (Eds), Plants for Environmental Studies, CRC Lewis Publishers, Boca Raton, New York, p. 308-333.

HAROUN SA AND SHEHRI AM. 2001. Cytogenetic effects of Calotropis procera extract on Vicia faba L. Cytologia 66: 373-378.

HU H AND QIN YM. 2006. Grape seed proanthocyanidin extract induced mitochondria-associated apoptosis in human acute myeloid leukemia 14.3D10 cells. Chin Med J 119: 417-421.

KIHLMAN BA. 1971. Root tips for studying the effects of chemicals on chromosomes. In: Hollaender A, Chemical Mutagens; Plenum Press New York, p. 489-504.
LAEMMLI UK. 1970. Cleavage of structural proteins during the assembly of the head of bacteriophage T4. Nature 227: 680-685.

LALROTLUANGA, KUMAR NS AND GURUSUBRAMANIAN G. 2011. Evaluation of the random amplified polymorphic DNA RAPD assay for the detection of DNA damage in mosquito larvae treated with plant extracts. Sci Vis 11(3): 155-158.

LEI ZS, GALE KR, He ZH, GiAnibelli C, LARRoQUe O, XiA XC, BUTOW BJ AND MA W. 2006. Y-type gene markers for enhanced discrimination of high molecular weight glutenin alleles at the Glu-B1 locus in hexaploid wheat. J Cereal Sci 43: 94-101.

LIU W, LI PJ, QI XM, ZHOU QX, ZHENG L, SUN TH AND YANG YS. 2005. DNA changes in barley Hordeum vulgare seedlings induced by cadmium pollution using RAPD analysis. Chemosphere 61: 158-167.

Lubini G, FAChinetTo JM, LAughinghouse HD, PARANHOS JT, SILVA ACF AND COSTA EC. 2008. Extracts affecting mitotic division in root-tip meristematic cells. Biologia 63: 647-651.

MA X, WANG X AND LIU Y. 2012. Cytotoxicity and genotoxicity evaluation of urban surface waters using freshwater luminescent bacteria Vibrio-qinghaiensis sp.-Q67 and Vicia faba root tip. J Environ Sci (China) 24(10): 18611866.

MONTANARI JI. 2002. Aspectos da produção comercial de plantas medicinais nativas. www.cpqba.unicamp.br/plmed/ artigos/ producao.htm.

MOUSSA SAI, TAIA WK AND AL-GHAMDY FGM. 2012. Acclimation of Dipterygium glaucum Decne grown in the Western Coastal part of Saudi Arabia to different water supplies. Int J Res Chem Environ 2: 301-309.

OlADUNMOYE MK, ADETUYi FC AND AKInYosoye FA. 2007. Effect of Cassia hirsuta L. extract on DNA profile of some microorganisms. Asian J of Bioch. 2: 142-146.

SAAD B, AZAizeh H, ABU-HiJleH G AND SAID O. 2006. Safety of Traditional Arab Herbal Medicine. Evid Based Complement Alternat Med 3: 433-439.

SINHA SC. 1996. Medicinal Plants of Manipur. Manipur Association for Science and Society, MASS \& Sinha, 238 p.

SOBITA K AND BHAGIRATH T. 2005. Effects of some medicinal plant extracts on Vicia faba root tip chromosomes. Caryologia 58 3: 255-261.

SOUSA SM, SILVA PS, CAMPOS JMS AND VICCINI LF. 2009. Cytotoxic and genotoxic effects of two medicinal species of Verbenaceae. Caryologia 62: 326-333.

WILLIAMS JG, KUBELIK AR, LIVAK KJ, RAFALSKI JA AND TINGEY SV. 1990. DNA polymorphisms amplified by arbitrary primers are useful as genetic markers. Nucleic Acids Res 18: 6531-6535.

YI H AND SI L. 2007. Vicia root-mirconucleus and sister chromatid exchange assays on the genotoxicity of selenium compounds. Mutat Res Gen Tox En 630: 92-96. 